\title{
Tumor suppressive microRNA-1285 regulates novel molecular targets:Aberrant expression and functional significance in renal cell carcinoma
}

\author{
Hideo Hidaka ${ }^{1, *}$, Naohiko Seki ${ }^{2,}{ }^{*}$, Hirofumi Yoshino ${ }^{1}$, Takeshi Yamasaki ${ }^{1}$, Yasutoshi \\ Yamada $^{1}$, Nijiro Nohata ${ }^{2}$, Miki Fuse ${ }^{2}$, Masayuki Nakagawa1 and Hideki Enokida ${ }^{1}$ \\ ${ }^{1}$ Department of Urology, Graduate School of Medical and Dental Sciences, Kagoshima University, Kagoshima, Japan \\ 2 Department of Functional Genomics, Graduate School of Medicine, Chiba University, Chiba, Japan \\ * Denotes equal contribution \\ Correspondence to: Hideki Enokida, email: enokida@m.kufm.kagoshima-u.ac.jp \\ Keywords: microRNA, expression signature, miR-1285, tumor suppressor, renal cell carcinoma, transglutaminase 2 \\ Received: December 31,2011, Accepted: January 21,2012, $\quad$ Published: January 30, 2012
}

Copyright: ( ) Hidaka et al. This is an open-access article distributed under the terms of the Creative Commons Attribution License, which permits unrestricted use, distribution, and reproduction in any medium, provided the original author and source are credited.

\section{ABSTRACT:}

MicroRNAs (miRNA) are non-coding RNAs, approximately 22 nucleotides in length, which function as post-transcriptional regulators. A large body of evidence indicates that miRNAs regulate the expression of cancer-related genes involved in proliferation, migration, invasion, and metastasis. The aim of this study was to identify novel cancer networks in renal cell carcinoma (RCC) based on miRNA expression signatures obtained from RCC clinical specimens. Expression signatures revealed that 103 miRNAs were significantly downregulated $(<0.5$-fold change) in RCC specimens. Functional screening (cell proliferation assays) was performed to identify tumor suppressive activities of 20 downregulated miRNAs. Restoration of mature miRNAs in cancer cells showed that 14 miRNAs (miR-1285, miR-206, miR-1, miR-135a, miR-429, miR-200c, miR-1291, miR-133b, miR-508-3p, miR-360-3p, miR509-5p, miR-218, miR-335, miR-1255b and miR-1285) markedly inhibited cancer cell proliferation, suggesting that these miRNAs were candidate tumor suppressive miRNAs in RCC. We focused on miR-1285 because it significantly inhibited cancer cell proliferation, invasion, and migration following its transfection. We addressed miR-1285-regulated cancer networks by using genome-wide gene expression analysis and bioinformatics. The data showed that transglutaminase 2 (TGM2) was directly regulated by $m i R-1285$. Silencing of the target gene demonstrated significant inhibition of cell proliferation and invasion in the RCC cells. Furthermore, immunohistochemistry showed that TGM2 expression levels in RCC specimens were significantly higher than those in normal renal tissues. Downregulation of tumor suppressive miR-1285, which targets oncogenic genes including TGM2, might contribute to RCC development. Thus, miR-1285 modulates a novel molecular target and provides new insights into potential mechanisms of RCC oncogenesis.

\section{INTRODUCTION}

Renal cell carcinoma (RCC) is the most common neoplasm of the adult kidney, and clear cell RCC represents the most common renal cancer histology [1]. Despite increased early detection of RCC and more frequent surgery, the mortality rate has not changed significantly during the last two decades $[2,3]$. New therapeutic drugs have been developed for treatment of metastatic RCC. However it is difficult to treat patients with metastatic RCC and prognostic improvement cannot be achieved. Therefore, it is crucial to find novel molecular mechanisms based on recent genome-wide studies including non-coding RNAs (ncRNA) in RCC oncogenesis and metastasis.

RNA can be divided into two categories, protein 
coding RNA and ncRNA. It is important to examine the functions of ncRNAs and their association with human disease, including cancer. microRNAs (miRNAs) are endogenous small ncRNA molecules ( 19 - 22 bases) that regulate protein coding gene expression by repressing translation or cleaving RNA transcripts in a sequencespecific manner [4]. A growing body of evidence suggests that miRNAs are aberrantly expressed in many human cancers, and that they play significant roles in their initiation, development, and metastasis [5]. Some highly expressed miRNAs could function as oncogenes by repressing tumor suppressors, whereas low level miRNAs could function as tumor suppressors by negatively regulating oncogenes [6].

Genome-wide miRNA expression signatures can rapidly and precisely reveal aberrant expression of miRNA in cancers. Thus, we have conducted miRNA expression signature analyses and searched for tumor suppressive miRNAs in various types of cancers [7-9]. Our previous studies successfully identified several tumor suppressive miRNAs such as miR-1, miR-133a, miR-145, miR-489, $m i R-218, m i R-375$ and $m i R-874$ [8-13].

The aim of this study was to identify new tumor suppressive miRNAs revealed in our expression signature analyses of clinical RCC specimens. We focused on miR1285 , which had the greatest inhibitory effect on cell proliferation in our functional analysis. We also used genome-wide gene expression analysis to search for novel targets regulated by $m i R-1285$ in RCC cells. Our data showed that 11 genes had putative target sites for $m i R$ 1285 in their 3'-untranslated regions (3'UTR). Tumor suppressive miR-1285 mediates novel molecular targets and provides new insights into the potential mechanisms of RCC oncogenesis.

\section{RESULTS}

\section{Identification of downregulated miRNAs in RCC: assessment of miRNA expression signatures}

We evaluated mature miRNA expression levels of clinical RCC specimens (ten cancer tissues and five adjacent non cancerous tissues) by miRNA expression signature analysis. Expression signatures revealed that 103 miRNAs were downregulated ( $<0.5$-fold change) in RCC specimens (Supplementary Table 1). The top 20 miRNAs

Table 1: Down-regulated microRNAs in renal cell carcinoma (RCC)

\begin{tabular}{|c|c|c|c|c|}
\hline microRNA & P-value & Normal & Cancer & $\begin{array}{c}\text { Fold Change } \\
\text { (Cancer/Normal) }\end{array}$ \\
\hline hsa-miR-141 & 0.022 & 1.237 & 0.026 & 0.021 \\
\hline hsa-miR-200c & 0.022 & 1.104 & 0.024 & 0.021 \\
\hline hsa-miR-187 & 0.007 & 1.526 & 0.043 & 0.028 \\
\hline hsa-miR-509-5p & 0.003 & 1.196 & 0.050 & 0.042 \\
\hline hsa-miR-135a & 0.003 & 1.525 & 0.099 & 0.065 \\
\hline hsa-miR-508-3p & 0.007 & 1.321 & 0.096 & 0.072 \\
\hline hsa-miR-1285 & 0.020 & 1.777 & 0.171 & 0.096 \\
\hline hsa-miR-206 & 0.013 & 1.580 & 0.192 & 0.121 \\
\hline hsa-miR-218 & 0.005 & 1.506 & 0.197 & 0.130 \\
\hline hsa-miR-133b & 0.006 & 1.173 & 0.173 & 0.147 \\
\hline hsa-miR-1291 & 0.019 & 1.978 & 0.310 & 0.157 \\
\hline hsa-let-7g* & 0.031 & 1.508 & 0.247 & 0.164 \\
\hline hsa-miR-204 & 0.014 & 1.468 & 0.254 & 0.173 \\
\hline hsa-miR-429 & 0.003 & 1.267 & 0.222 & 0.175 \\
\hline hsa-miR-370 & 0.042 & 1.525 & 0.268 & 0.176 \\
\hline hsa-miR-363 & 0.010 & 1.377 & 0.244 & 0.177 \\
\hline hsa-miR-335 & 0.005 & 1.226 & 0.224 & 0.182 \\
\hline hsa-miR-1 & 0.005 & 1.017 & 0.189 & 0.186 \\
\hline hsa-miR-1255B & 0.020 & 1.306 & 0.248 & 0.190 \\
\hline hsa-miR-362-3p & 0.010 & 1.501 & 0.312 & 0.208 \\
\hline & & & & \\
\hline & & & \\
\hline & & & \\
\hline & & & \\
\hline
\end{tabular}


A

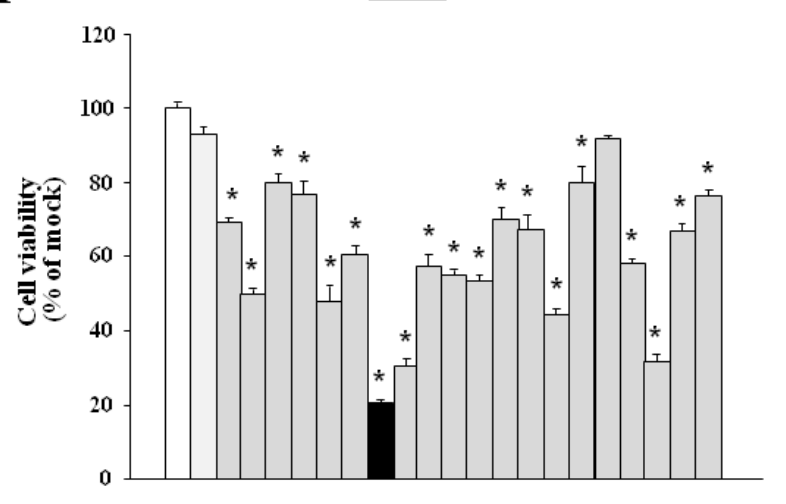

C

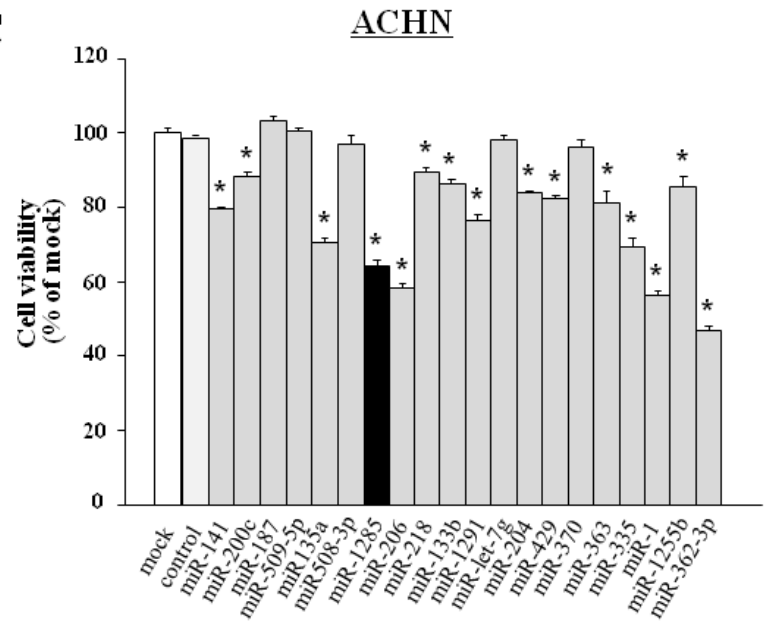

$\mathbf{E}$

$\underline{\text { miR-1285 expression }}$

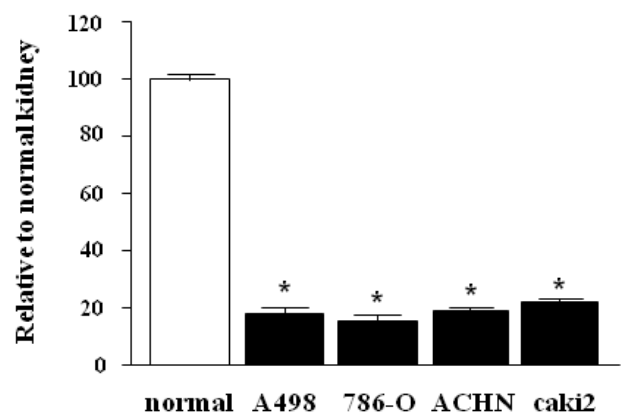

B

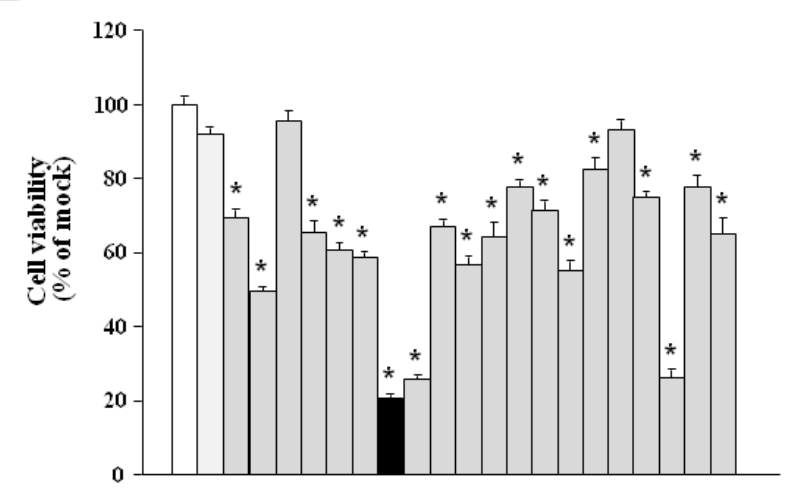

D

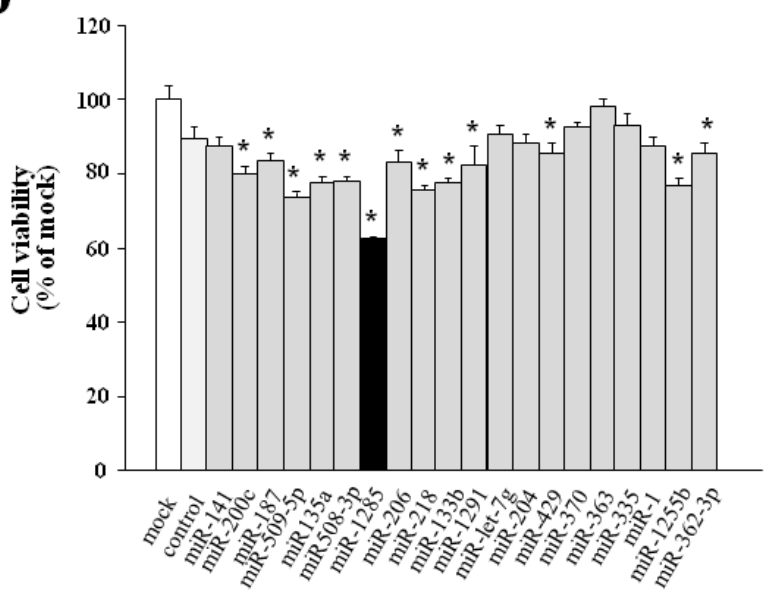

F

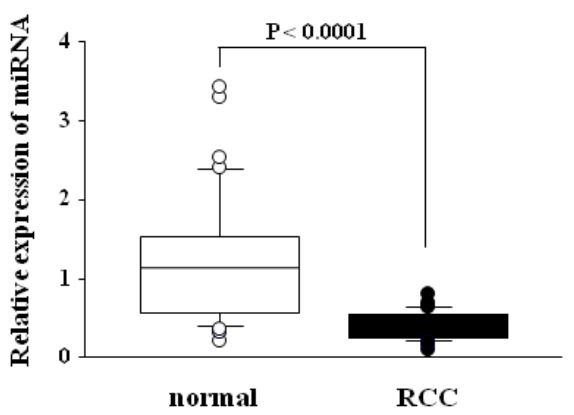

Figure 1: Screening of tumor suppressive microRNAs in RCC. (A-D) Effect of cell proliferation determined by XTT assays using mature miRNAs (miR-141, miR-200c, miR-187, miR-509-5p, miR-135a, miR-508-3p, miR-1285, miR-206, miR-218, miR-133b, miR1291, let-7g* $m i R-204, m i R-429, m i R-370, m i R-363, m i R-335, m i R-1, m i R-1255 b$, and $m i R-362-3 p$ ) after $72 \mathrm{~h}$ transfection of RCC cell lines (A498, 786-O, ACHN and caki2). ${ }^{*} \mathrm{P}<0.0001$. (E) Expression levels of $m i R-1285$ in RCC cell lines. miR-1285 expression levels were significantly downregulated in all cell lines in comparison with normal kidney.(F) Expression levels of $m i R-1285$ in clinical RCC specimens. Relative miR-1285 expression levels are expressed in box plots. RNU48 was used as the internal control. 
A

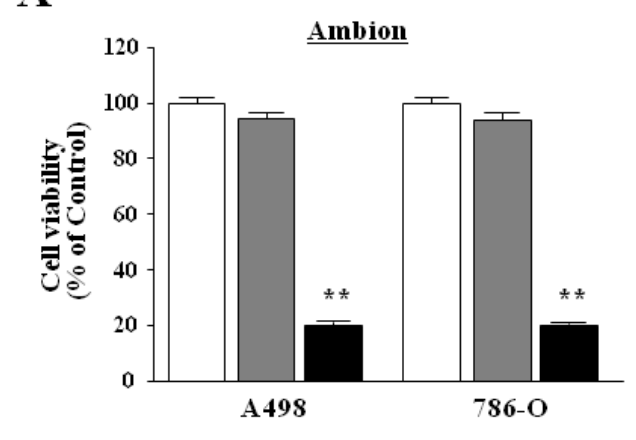

$\underline{\text { XTT assay }}$
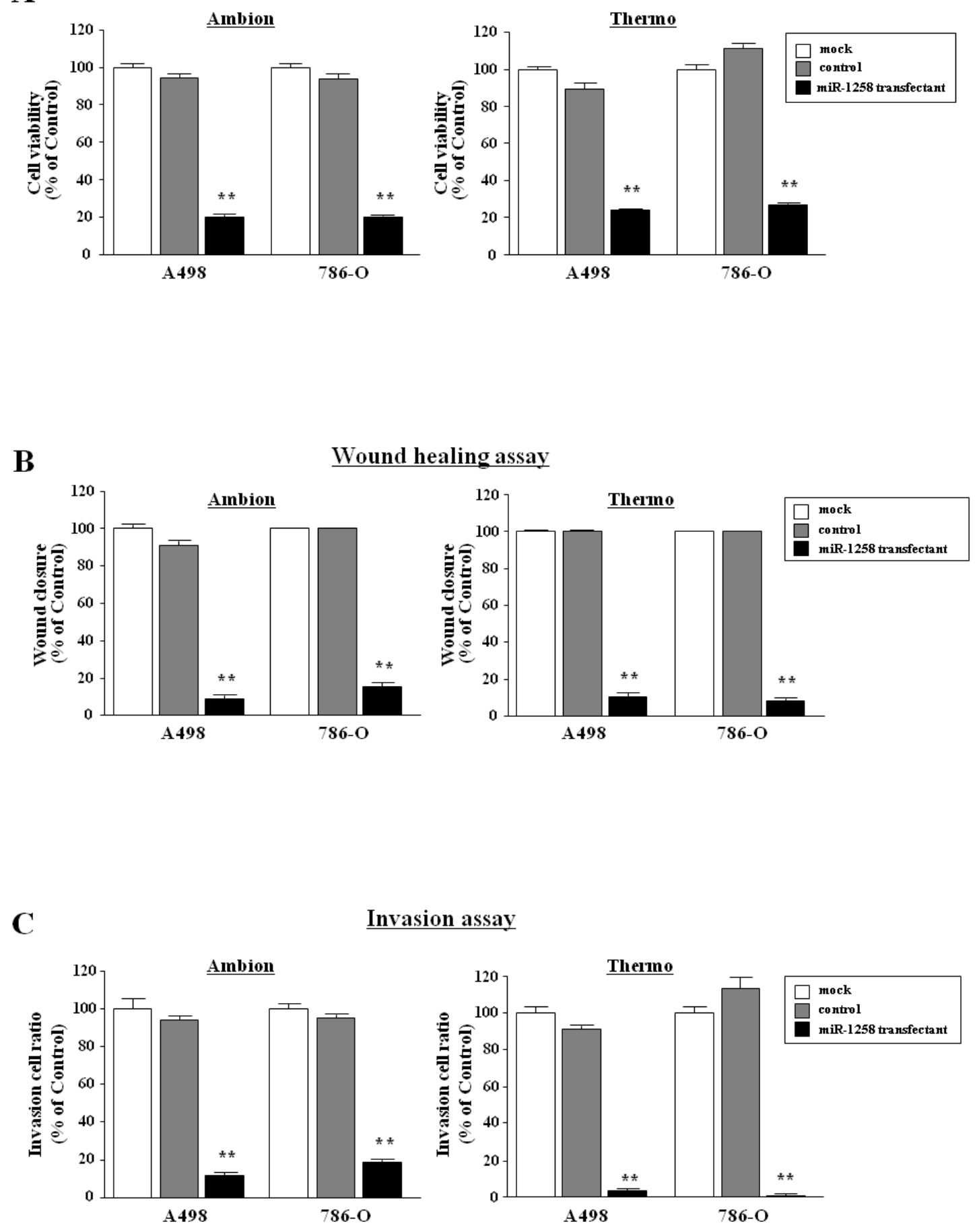

Figure 2: Effect of mature miR-1285 transfection in RCC cell lines.(A) Cell proliferation was determined with XTT assays of

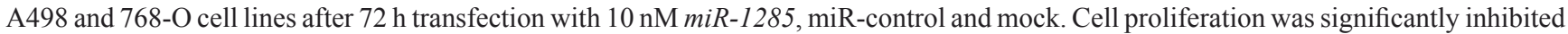
in miR-1285 transfectants in comparison with the mock cells. Thus, with the Ambion products, the percentage of cell viability relative to mock cells was $20.3 \pm 1.7 \%$ for A 498 , and $20.1 \pm 0.7 \%$ for $786-\mathrm{O}$ (both $\mathrm{P}<0.0001$ ). For the Thermo products, the percentages were 24.1 $\pm 1.1 \%$ (A498) and $27.1 \pm 1.3 \%$ (786-O)(both $\mathrm{P}<0.0001)$ (Figure 2A).(B) Cell migration activity was determined with the wound healing assay after $48 \mathrm{~h}$ transfection of $m i R-1285$. Cell migration was significantly inhibited in $m i R-1285$ transfectants in comparison with the mock. Thus, with the Ambion materials, the percentage of wound closure relative to mock was $9 \pm 6.7 \%$ for A498, and $15.4 \pm 7.0$ for $786-\mathrm{O}$ (both, $\mathrm{P}<0.0001$ ). With the Thermo miRNAs, the values were $10.4 \pm 6.0 \%$ (A498), and $8.2 \pm 3.6 \%$ (786-O) (both $\mathrm{P}<0.0001$ ) (Figure 2B). (C) Cell invasion activity was determined with the Matrigel invasion assay after $48 \mathrm{~h}$ transfection of $m i R-1285$. Cell numbers significantly decreased after $m i R-1285$ transfection in comparison with the mock. Thus, using Ambion miRNA, the percentage of cell invasion relative to mock was $11.7 \pm 0.7$ (A498) and $18.6 \pm 3.2 \%(786-\mathrm{O})($ both $\mathrm{P}<0.0001)$. With the Thermo products, we observed $3.1 \pm 0.5 \%(\mathrm{~A} 498)$ and $0.4 \pm 0.7 \%$ (786-O) (both $\mathrm{P}<0.0001$ ) (Figure $2 \mathrm{C}$ ). $* * \mathrm{P}<0.0001$. 
(miR-141, miR-200c, miR-187, miR-509-5p, miR-135a, miR-508-3p, miR-1285, miR-206, miR-218, miR-133b, miR-1291, miR-let-7g, miR-204, miR-429, miR-370, miR363, miR-335, miR-1, miR-1255B and miR-362-3p) in the expression list were subjected to further study (Table 1).

\section{Transfection of 20 downregulated miRNAs: effects on cancer cell proliferation}

To investigate the functional role of the 20 downregulated miRNAs, we performed gain-of-function studies using mature miRNA transfection in RCC cell lines. The XTT assay revealed significant inhibition of cell proliferation in several miRNA transfectants (A498, 786-O, ACHN and caki2) in comparison with mock transfectants (transfectant reagent only) (each, $\mathrm{P}<0.0001$, Figure 1A, B, C, and D). Supplementary Table 2 shows the extent to which cell proliferation was inhibited in four RCC cell lines. $m i R-1285$ transfection showed the greatest inhibitory effect among the 20 candidate miRNAs. Thus, we focused on $m i R-1285$ and investigated the functional significance using RCC cell lines.

\section{Expression levels of $m i R-1285$ in cancer cell lines and $R C C$ clinical specimens}

The expression levels of $m i R-1285$ were significantly lower in RCC cell lines (A498, 786-O, ACHN and caki2) than normal kidney (Figure 1E). Also, miR-1285 expression was significantly reduced in RCC clinical specimens compared with adjacent non-cancerous tissues $(\mathrm{P}<0.0001$, Figure 1F).

\section{Effect of miR-1285 restoration on cell proliferation, migration and invasion in RCC cell lines}

To investigate the functional significance of $m i R$ 1285, we performed gain-of-function studies using transient transfection with mature $m i R-1285$. We utilized two sources of mature miR-1285 (Ambion and Thermo) to ensure reproducibility of the data.

The XTT assay demonstrated that cell proliferation was significantly inhibited in $m i R-1285$ transfectants in comparison with the mock cells (Figure 2A).

The wound healing assay demonstrated that cell

Table 2: Down-regulated genes in miR-1285 transfectants

Fold change (log 2 ratio)

\begin{tabular}{|c|c|c|c|c|c|c|}
\hline Entrez gene ID & Symbol & A498 & $786-0$ & Average & Gene name & Target site \\
\hline 64077 & LHPP & -2.98 & -3.92 & -3.45 & $\begin{array}{l}\text { Phospholysine phosphohistidine inorganic } \\
\text { pyrophosphate phosphatase }\end{array}$ & + \\
\hline 4771 & NF2 & -2.99 & -3.02 & -3.01 & Neurofibromin 2 & + \\
\hline 1979 & EIF4EBP2 & -2.79 & -3.11 & -2.95 & $\begin{array}{l}\text { Eukaryotic translation initiation factor } 4 \mathrm{E} \\
\text { binding protein } 2\end{array}$ & - \\
\hline 7052 & TGM2 & -2.44 & -3.12 & -2.78 & Transglutaminase 2 & + \\
\hline 114902 & C1QTNF5 & -2.64 & -2.83 & -2.74 & $\begin{array}{l}\mathrm{C} 1 \mathrm{q} \text { and tumor necrosis factor related } \\
\text { protein } 5\end{array}$ & - \\
\hline 3773 & KCNJ16 & -2.45 & -3.00 & -2.72 & $\begin{array}{l}\text { Potassium inwardly-rectifying channel, } \\
\text { subfamily J, member } 16\end{array}$ & + \\
\hline 54901 & CDKAL1 & -2.96 & -2.31 & -2.64 & $\begin{array}{l}\text { CDK5 regulatory subunit associated protein } \\
\text { 1-like } 1\end{array}$ & - \\
\hline 51148 & CERCAM & -2.52 & -2.61 & -2.56 & $\begin{array}{l}\text { Cerebral endothelial cell adhesion } \\
\text { molecule }\end{array}$ & + \\
\hline 11346 & SYNPO & -2.41 & -2.58 & -2.49 & Synaptopodin & + \\
\hline 441518 & FAM127C & -2.09 & -2.67 & -2.38 & $\begin{array}{l}\text { Family with sequence similarity } 127 \text {, } \\
\text { member } C\end{array}$ & + \\
\hline 254439 & C11orf86 & -2.41 & -2.29 & -2.35 & Chromosome 11 open reading frame 86 & - \\
\hline 83742 & MARVELD1 & -2.26 & -2.41 & -2.34 & MARVEL domain containing 1 & - \\
\hline 9718 & ECE2 & -2.14 & -2.50 & -2.32 & Endothelin converting enzyme 2 & - \\
\hline 4907 & NT5E & -2.27 & -2.31 & -2.29 & 5'-nucleotidase, ecto (CD73) & + \\
\hline 11313 & LYPLA2 & -2.09 & -2.31 & -2.19 & Lysophospholipase II & + \\
\hline 79026 & AHNAK & -2.07 & -2.26 & -2.16 & AHNAK nucleoprotein & + \\
\hline 51313 & FAM198B & -2.03 & -2.11 & -2.07 & $\begin{array}{l}\text { Family with sequence similarity } 198, \\
\text { member B }\end{array}$ & + \\
\hline
\end{tabular}


migration was significantly inhibited in $m i R-1285$ transfectants in comparison with the mock (Figure 2B).

The Matrigel invasion assay demonstrated that invading cell numbers significantly decreased after $m i R$ 1285 transfection in comparison with the mock (Figure 2C).

\section{Identification of $m i R-1285$ regulated target genes by genome-wide gene expression analysis and validation of target genes using clinical RCC specimens}

To gain further insight into which genes were affected by $m i R-1285$ transfection, we performed microarray analysis of miR-1285 transfectants (A498 and 786-O). A total of 17 genes were downregulated (less than -2.0-fold changes) in miR-1285 transfectants compared with the controls. The TargetScan program revealed that seven of 17 downregulated genes had putative target sites of miR-1285 in their 3'UTRs (Table 2).

Seven of the downregulated genes in miR1285transfectants (LHPP, TGM2, NF2, CERCAM, SYNPO, $L Y P L A 2$, and $A H N A K$ ) were selected and we measured the mRNA expression levels in the clinical RCC samples by quantitative real-time RT-PCR. Among them, TGM2 was the only gene that was expressed significantly higher in RCC specimens than in adjacent non-cancerous tissues $(\mathrm{P}<0.0037$, Figure 3A). Therefore, we focused on TGM2 as a promising candidate target of $m i R-1285$.

\section{$m i R-1285$ directly regulates $T G M 2$ in RCC cell lines}

Quantitative real-time RT-PCR analyses showed that mRNA expression levels of TGM2 in the A498 and 786-O cell lines were higher than those in normal human kidney (Figure 3B). Furthermore, both TGM2 mRNA and TGM2 protein expression levels were markedly downregulated in $m i R-1285$ transfectants in comparison with the control transfectants (A498 and 786-O) (Figure 3C, D).

To determine whether the 3'-UTR of TGM2 had an actual target site for $m i R-1285$, we performed a luciferase reporter assay by using a vector encoding the full-length 3'UTR of TGM2 mRNA and found that the luminescence intensity was significantly reduced in the miR-1285 transfectants compared to the control-transfectant (Figure 3E).

\section{Effect of TGM2 silencing on cell proliferation, migration and invasion in RCC cell lines}

To examine the functional role of TGM2, we performed loss-of-function studies in A498 and 786-O cell lines transfected with two different sequences of si-TGM2.
The mRNA and protein expression levels of TGM2 were markedly repressed by these si-TGM2 transfections (Figure 4A, B).

The XTT assay revealed that significant inhibition of cell proliferation was observed in the two si-TGM2 transfectants in comparison with the untransfectants (mock) and the si-control transfectants (Figure 5A).

The wound healing assay also demonstrated significant cell migration inhibitions in the two si-TGM2 transfectants compared with the counterparts (Figure 5B).

The matrigel invasion assay demonstrated that the number of invading cell was significantly decreased in the two si-TGM2 transfectants compared with the counterparts (Figure 5C).

\section{Immunohistochemistry of TGM2}

Figure 6 shows the representative results of immunohistochemical staining of TGM2. TGM2 was strongly expressed in tumor lesions A (T1N0M0), B (T2N0M0) and C (T3N0M0), whereas no expression was observed in normal tissue (D). The expression score of the tumor was significantly higher than that of normal tissues $(\mathrm{P}=0.0004)(\mathrm{E}$, upper). We found that there were significant correlations between the expression scores and tumor stage $(\mathrm{P}=0.0111)(\mathrm{E}$, lower $)$.

\section{DISCUSSION}

In this study, we constructed miRNA expression signatures of clinical RCC specimens using 778 miRNAs by PCR-based analysis. Among them, 103 miRNAs were downregulated ( 0.5 -fold change) and the top 20 downregulated miRNAs were evaluated to determine whether these miRNAs had potential tumor suppressor functions. Our functional screening revealed that 14 miRNAs (miR-1285, miR-206, miR-1, miR-135a, miR-429, $m i R-200 c, m R-1291, m i R-133 b, m i R-508-3 p, m i R-362-3 p$, miR-509-5p, miR-218, miR-335, miR-1255b and miR-141) significantly inhibited cancer cell proliferation in RCC cell lines, suggesting that these miRNAs were potentially promising candidate tumor suppressive miRNAs.

In our previous studies of miRNA signatures, $m i R$ 206, $m i R-1, m i R-133 b$ and $m i R-218$ were significantly reduced in various types of cancers. We also observed that restoration of these miRNAs inhibited cancer cell proliferation, invasion and migration [10-16]. Our data strongly suggested that these miRNAs function as tumor suppressors in human cancers [10-16]. Of particular interest, $m i R-1-1 / m i R-133 a-2, m i R-1-2 / m i R$ $133 a-1$, and $m i R-206 / m i R-133 b$ form clusters on three different chromosomal regions in the human genome, $20 q 13.33,18 q 11.2$, and 6 p12.1, respectively $[17,18]$. We and other groups also demonstrated that these clusters were frequently downregulated in human cancers and 
significantly contributed to human oncogenesis $[8,10,19$ 22]. Our present signature of RCC supports previous results and it is expected that these function as tumor suppressors in RCC.

In this signature, $m i R-141, m i R-200 c, m i R-429$, $m i R-200 b$ and $m i R-200 a$ were significantly reduced in RCC. It is well known that the miR-200 family consists of five members organized as two clusters, $m i R-200 \mathrm{~b} / \mathrm{miR}$ $200 \mathrm{a} / \mathrm{miR}-429$ and $\mathrm{miR}-200 \mathrm{c} / \mathrm{miR}-141$, on chromosomes $1 \mathrm{p} 36.33$ and $12 \mathrm{p} 13.31$, respectively. The miR-200 family contains closely related seed sequences. It has been reported that one can inhibit the initiation of the epithelial-mesenchymal transition (EMT) by targeting $Z E B 1$ and ZEB2 [23,24]. Downregulation of the $m i R$ 200 family in our signature is supported by other reports of RCC signatures [25], and this fact suggests that the EMT pathway is a main theme of RCC oncogenesis. Our miRNA expression signature provides the important information for miRNA research fields of RCC oncogenesis and metastasis.

In this study, we focused on miR-1285 because it had the greatest inhibitory effect on cancer cell proliferation among 20 downregulated miRNAs in our signature. We investigated its functional significance and how it regulated molecular targets in RCC cells. miR-1285 was discovered from massive parallel sequencing of human embryonic stem cells [26], and it is a unique miRNA that exists in a limited group of animals including Homo sapiens, Pan troglodytes, Sus scrofa and Pongo pygmaeus (miRBase: http:/www.mirbase.org/index.shtml). In the human genome, miR-1285 mapped on two different chromosomes ( $m i R-1285-1$ at $7 \mathrm{q} 21.2$ and $m i R-1285-2$ at $2 \mathrm{p} 13.3$ ), and the mature miRNA sequences are identical. There are few publications focused on $m i R-1285$. This is the first report that $m i R-1285$ is downregulated in clinical RCC specimens and demonstrates that it functions as a tumor suppressor.

miRNAs are unique in their ability to regulate many protein coding genes. Bioinformatic predictions indicate that miRNAs regulate more than $30 \%$ of protein coding genes [27]. The elucidation of new molecular targets regulated by tumor suppressive $m i R-1285$ is important
A

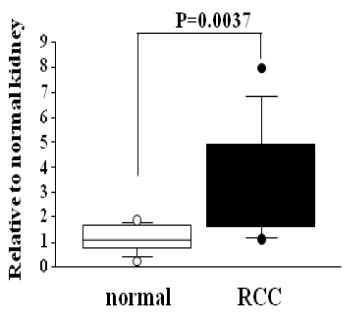

D
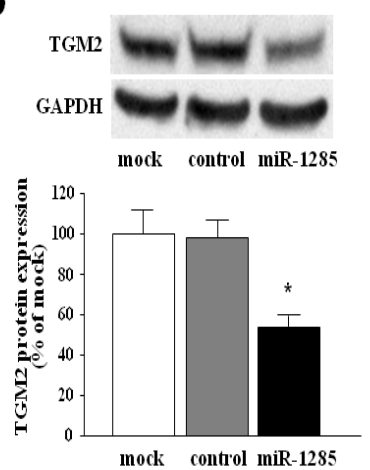

A498

\section{B}

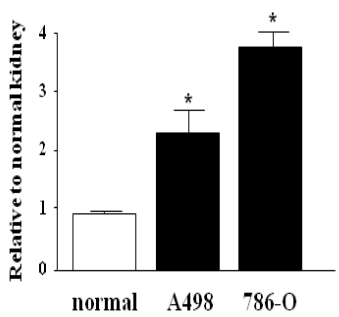

normal A498 $786-0$

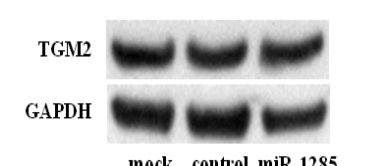

mock control miR-1285

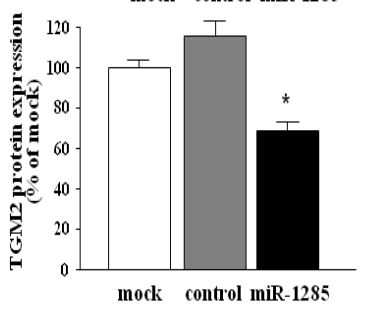

$786-0$
C
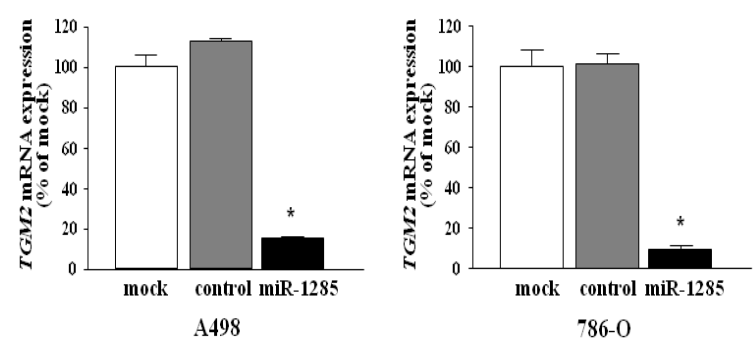

E
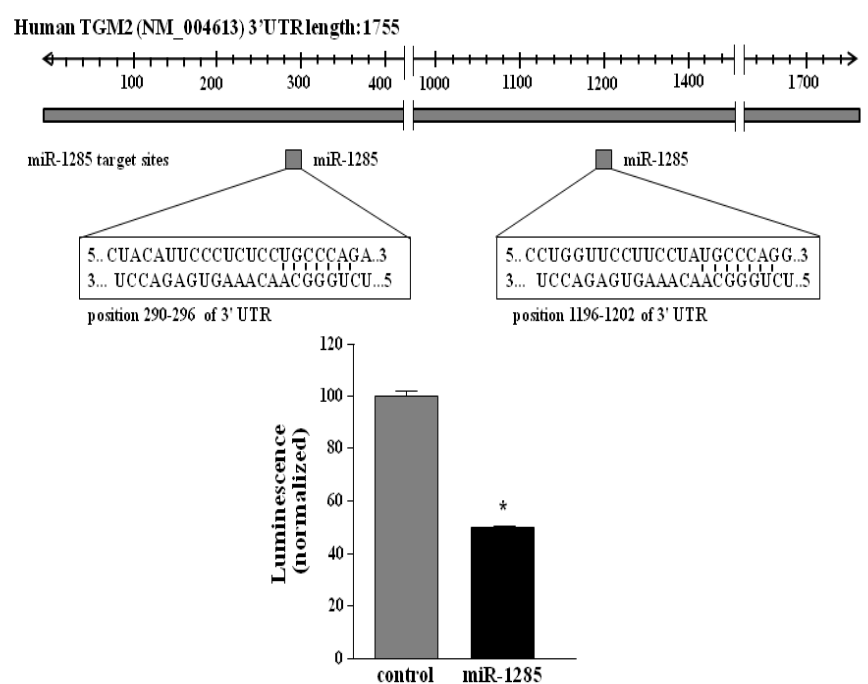

Figure 3: $\boldsymbol{m i R}-1285$ directly regulates $T G M 2$ in RCC cells. (A) Expression level of TGM2 mRNA in clinical RCC cell specimens. Relative TGM2 mRNA expression levels are expressed in box plots. (B) The mRNA expression levels of TGM2 in RCC cell lines (A498 and 786-O) compared to normal kidney RNA. GUSB was used as an internal control.(C) TGM2 mRNA expression in RCC cell lines (A498 and 786-O). TGM2 mRNA expression $24 \mathrm{~h}$ after transfection with $10 \mathrm{nM} \mathrm{miR-1285.} \mathrm{GUSB}$ was used as an internal control. (D) TGM2 protein expression in RCC cell lines (A498 and 786-O).TGM2 protein expression $72 \mathrm{~h}$ after transfection with $10 \mathrm{nM} m i R-1285$. GAPDH was used as a loading control.E) miRNA-1285 binding sites in the 3'UTR of TGM2 mRNA. A luciferase assay using the vector encoding full-length 3'UTR of TGM2 mRNA. The Renilla luciferase values were normalized to firefly luciferase values. $* \mathrm{P}<0.0001$ 
for our understanding of RCC oncogenesis. Based on this view, we have performed to search miR-1285 regulated molecular targets by using genome-wide gene expression analysis.

In this study, we identified seven target genes (LHPP, TGM2, NF2, CERCAM, SYNPO, LYPLA2, and $A H N A K)$ downregulated in miR-1285-transfected cells and found they contained miR-1285 target sites in their 3'UTR. Next, we investigated the mRNA expression levels of seven candidate genes using clinical RCC specimens. $T G M$ was the most upregulated gene in cancer cells. Thus, we examined the role of TGM2 in RCC cells. TGM2 is a family of enzymes that catalyzes the formation of an amide bond between the $\gamma$-carboxamide groups of peptidebound glutamine residues and the primary amino group in various compounds [28,29]. TGM2 is known to play an important role in cancer. Increased expression of TGM2 has been observed in many types of cancer, including pancreatic cancer [30], breast cancer [31], malignant melanoma [32], ovarian cancer [33], lung cancer [34], and glioblastoma [35]. In addition, several investigators showed that increased expression of TGM2 might be linked to increased drug resistance, metastasis, and the epithelial to mesenchymal transition (EMT) [36-39]. Our present data support reports finding that TGM2 functions as an oncogene in RCC.

In conclusion, miR-1285 was significantly downregulated in RCC cell lines, was frequently reduced in clinical specimens, and functioned as a tumor suppressor in RCC. Our data indicated that upregulation of oncogenic TGM2 may be due to downregulation of tumor suppressive miR-1285 in human RCC progression. This novel molecular network may play a critical role in RCC oncogenesis and serve as a novel therapeutic strategy for patients with RCC.

\section{A}

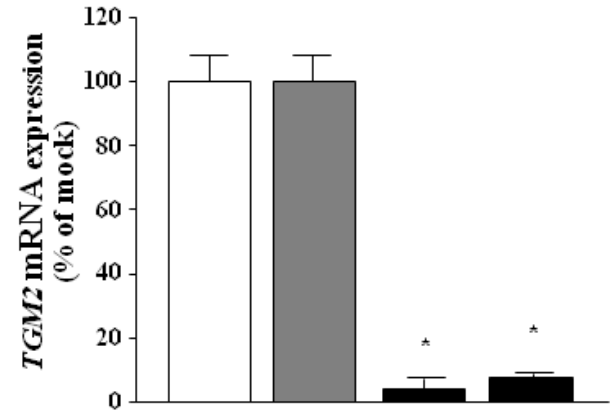

A498

B
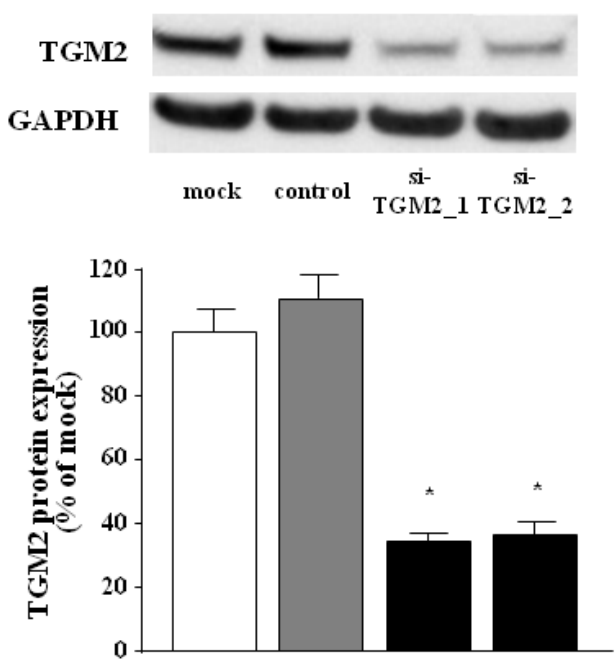

A498

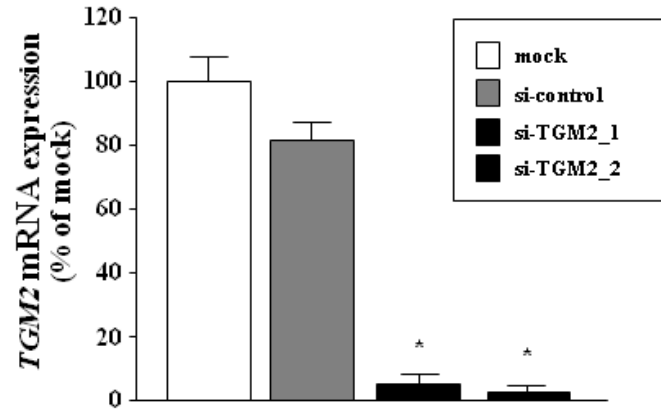

786-O
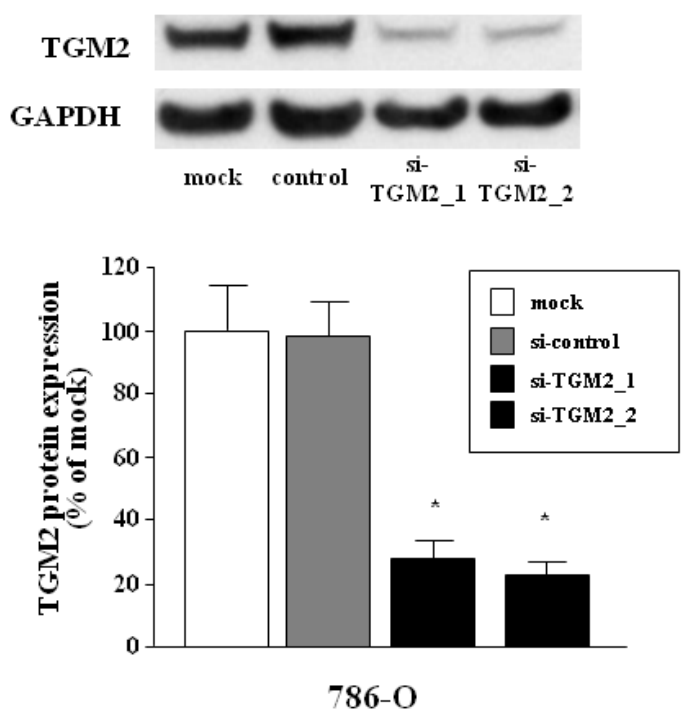

Figure 4: Silencing of TGM2 in two RCC cell lines by si-TGM2.(A) TGM2 mRNA expression after 24 hr of transfection with $10 \mathrm{nM}$ si-TGM2 in RCC cell lines (A498 and 786-O). GUSB was used as an internal control. (B) TGM2 protein expression after $72 \mathrm{hr}$ transfection with si-TGM2. GAPDH was used a loading control. $* \mathrm{P}<0.0001$. 


\section{METHODS}

\section{RCC Clinical specimens and RCC cell lines}

Following nephrectomies at Kagoshima University Hospital, a total of five pairs of clear cell type cancer and adjacent non-cancerous tissue, and an additional group of five clear cell type cancer were collected for miRNA expression analysis (supplementary Table 3, Number 1-15). The tissue specimens for quantitative RT-PCR were from 36 RCC patients who had undergone nephrectomy at Kagoshima University Hospital between 2006 and 2009 (supplementary Table 3, Numbers 6 - 43). These samples were staged according to the American Joint Committee on Cancer-Union Internationale Contre le Cancer (UICC) tumor-node-metastasis classification and histologically graded [40]. Our study was approved by the Bioethics Committee of Kagoshima University; written prior informed consent and approval were given by the patients.

We used four human RCC cell lines: A498, 786-O, $\mathrm{ACHN}$ and caki-2 that were obtained from the American Type Culture Collection (Manassas, VA, USA). These cell lines were incubated in RPMI 1640 medium (Invitrogen, Carlsbad, CA, USA) supplemented with $10 \%$ fetal bovine serum and maintained in humidified incubators $(5 \% \mathrm{CO} 2)$ at $37^{\circ} \mathrm{C}$.

Total RNA including miRNA was extracted using the mirVana miRNA isolation kit (Ambion, Austin, TX, USA) following the manufacturer's protocol. The integrity of the RNA was checked with the RNA 6000 Nano Assay Kit and a 2100 Bioanalyzer (Agilent Technologies, Santa Clara, CA, USA).

\section{miRNA expression signatures and data normalization}

MiRNA expression patterns were evaluated using the TaqMan LDA Human microRNA Panel v2.0; a total of 778 miRNAs were investigated in the screen (Applied Biosystems, Foster City, CA, USA). The assay was composed of two steps: generation of cDNAs by reverse transcription and a TaqMan real-time PCR assay. The description of real-time PCR and the list of human miRNAs can be found on the company's website (http:// www.appliedbiosystems.com). An analysis of relative miRNA expression data was performed using GeneSpring GX version 7.3.1 software (Agilent Technologies) according to the manufacturer's instructions. A cutoff $\mathrm{P}$ value $<0.05$ was used to narrow down the candidates after global normalization of the raw data. After global normalization, the additional normalization was done with RNU48.

\section{Quantitative real-time RT-PCR}

TaqMan probes and primers for TGM2 (P/N: Hs00190278_m1; Applied Biosystems) were assay-ondemand gene expression products. All reactions were performed in duplicate and a negative control lacking cDNA was included. We followed the manufacturer's protocol for PCR conditions. Stem-loop RT-PCR (TaqMan MicroRNA Assays; P/N: PM13580 for miR1285; Applied Biosystems) was used to quantitate miRNAs according to earlier published conditions (11). To normalize the data for quantification of TGM2 mRNA and the miRNAs, we used human GUSB (P/N: Hs99999908 $\mathrm{m} 1$; Applied Biosystems) and RNU48 (P/N: 001006; Applied Biosystems), respectively, and the delta-delta $\mathrm{Ct}$ method was employed to calculate the fold-change. As a control RNA, we used total RNA from our normal human kidneys sample.

\section{Mature miRNA and siRNA transfection}

As described elsewhere (11), the RCC cell lines were transfected with Lipofectamine RNAiMAX transfection reagent (Invitrogen) and Opti-MEM (Invitrogen) with $10 \mathrm{nM}$ mature miRNA molecules. PremiR (Applied Biosystems and Thermo Fisher Scientific) and negative control miRNA (Applied Biosystems) were used in the gain-of-function experiments, whereas TGM2 siRNA (Cat numbers, SASI_Hs01_00035266 and SASI_Hs02_00338000, Sigma Aldrich) and negative control siRNA (MISSION siRNA Universal Negative Control, Sigma Aldrich) were used in the loss-of-function experiments. Cells were seeded in ten $\mathrm{cm}$ dishes for protein extraction $\left(8 \times 10^{5}\right.$ cells per dish), in six well plates for wound healing assays $\left(20 \times 10^{4}\right.$ cells per well $)$, in a 24 well plates for mRNA extraction and luciferase reporter assays $\left(5 \times 10^{4}\right.$ cells per well), and in 96 well plates for XTT assays (3000 cells per well).

\section{Cell proliferation, migration and invasion assays}

Cell proliferation was determined using an XTT assay (Roche Applied Sciences, Tokyo, Japan) performed according to the manufacturer's instructions. Cell migration activity was evaluated with a wound-healing assay. Cells were plated in six well dishes, and the cell monolayer was scraped using a P-20 micropipette tip. The initial gap length $(0 \mathrm{~h})$ and the residual gap length $24 \mathrm{~h}$ after wounding were calculated from photomicrographs. A cell invasion assay was carried out using modified Boyden Chambers consisting of Transwell-precoated Matrigel membrane filter inserts with eight $\mathrm{mm}$ pores in 24 well tissue culture plates (BD Biosciences, Bedford, MA, USA). Minimum essential medium containing 


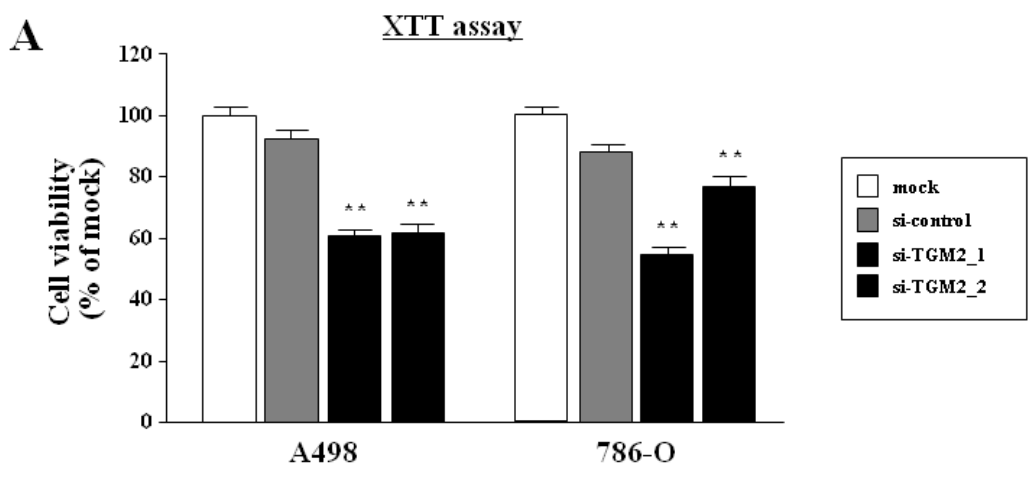

B Wound healing assay
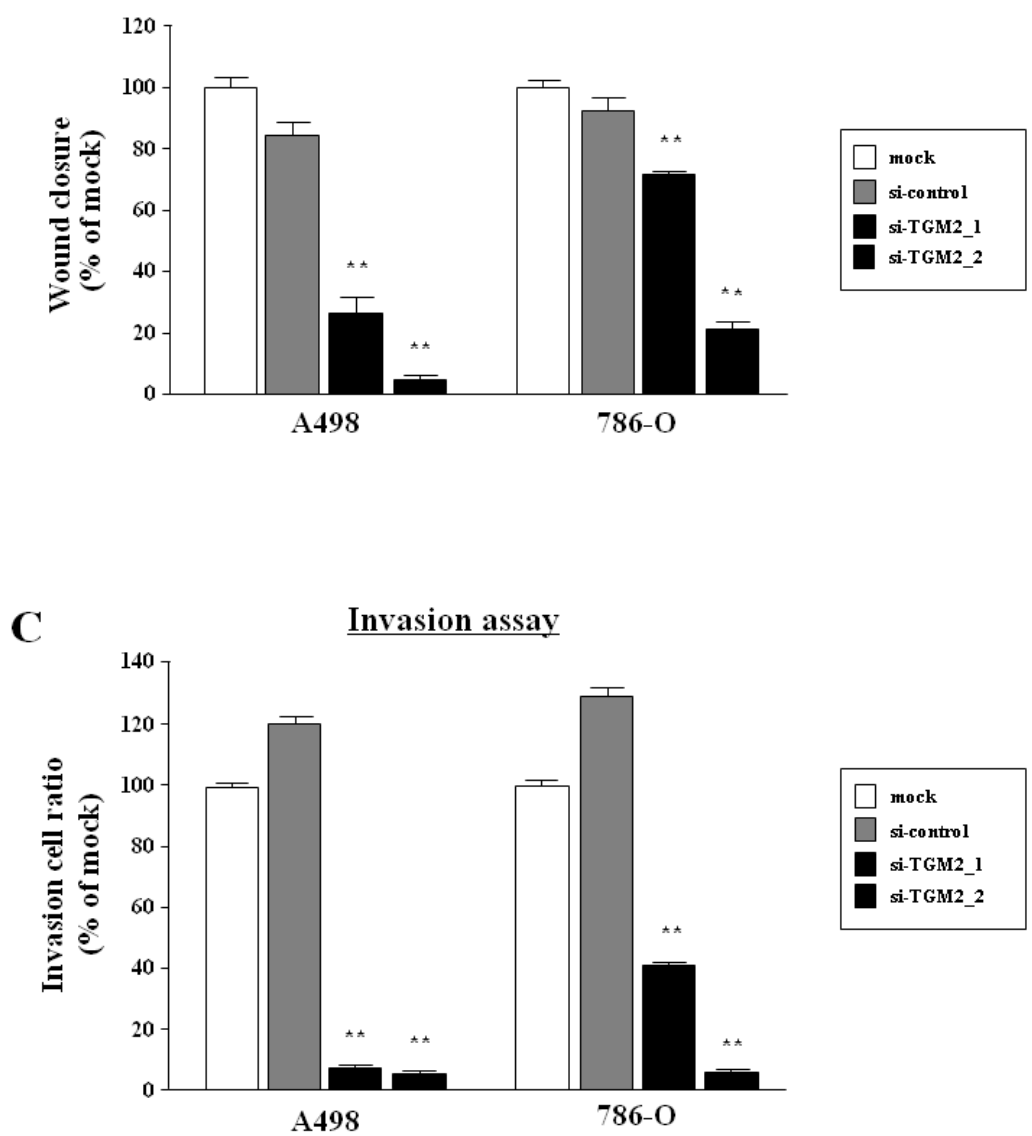

Figure 5: Effect of silencing of TGM2 in two RCC cell lines.(A) Cell proliferation determined with XTT assays of A498 and 768 -O cell lines after $72 \mathrm{~h}$ transfection with $10 \mathrm{nM}$ si-TRM2, miR-control or mock. Cell proliferation was significantly inhibited in the two si-TGM2 transfectants in comparison with the nontransfectants (mock) and the si-control transfectants. Thus, the percentage of cell viability for A498 was $60.6 \pm 4.2 \%, 62.0 \pm 5.9 \%, 100.0 \pm 5.5 \%$, and $92.3 \pm 6.3 \%$, respectively $(\mathrm{P}<0.0001)$. The percentage of cell viability for $786-\mathrm{O}$ was $54.7 \pm 4.7 \%, 76.9 \pm 17.9 \%, 100.0 \pm 6.7 \%$ and $88.1 \pm 5.5 \%$, respectively, $(\mathrm{P}<0.0001)$ (Figure 5A).(B) Cell migration activity determined with wound healing assays after $48 \mathrm{~h}$ transfection with si-TGM2. Cell migration was significantly inhibited in the two si-TGM2 transfectants compared with the counterparts. For A498, the percentage of wound closure was $26.3 \pm 14.4 \%, 4.1 \pm 3.9 \%, 100.0 \pm 9.4 \%$, and $84.3 \pm 13.0 \%$, respectively $(\mathrm{P}<0.0001)$. For $786-\mathrm{O}$, we observed closures of $71.2 \pm 4.9 \%, 20.8 \pm 6.4 \%, 100.0 \pm 7.5 \%$, and $92.7 \pm$ $13.3 \%$, respectively $(\mathrm{P}<0.0001)$ (Figure $5 \mathrm{~B})$. (C) Cell invasion activity determined with the Matrigel invasion assay after $48 \mathrm{~h}$ transfection with si-TGM2. The number of invading cells was significantly decreased in the two si-TGM2 transfectants compared with the counterparts. Specifically, the percentage of cell invasion for A498 was $7.3 \pm 2.6 \%, 5.1 \pm 1.9 \%, 100.0 \pm 4.0 \%$, and $120.7 \pm 4.0 \%$, respectively $(\mathrm{P}<$ $0.0001)$ and for $786-\mathrm{O}$, they were $40.7 \pm 3.8 \%, 55.0 \pm 51.2 \%, 100.0 \pm 3.7 \%$, and $136.4 \pm 8.1 \%$, respectively $(\mathrm{P}<0.0001)$ (Figure $5 \mathrm{C}$ ). ${ }^{* *} \mathrm{P}$ $<0.0001$. 
$10 \%$ fetal bovine serum in the lower chamber served as the chemoattractant as described previously (12). All experiments were performed in triplicate.

\section{Screening of miR-1285-regulated genes using microarray and database analysis}

Oligo-microarray Human 44K (Agilent) was used for expression profiling in $m i R-1285$-transfected RCC cell lines (A498 and 786-O) in comparison with miRnegative control transfectants, as previously described (12). Briefly, hybridization and washing steps were performed in accordance with the manufacturer's instructions. The arrays were scanned using a Packard
GSI Lumonics ScanArray 4000 (PerkinElmer, Boston, MA, USA). The data obtained were analyzed with DNASIS array software (Hitachi Software Engineering, Tokyo, Japan), which converted the signal intensity for each spot into text format. The $\log _{2}$ ratios of the median subtracted background intensity were analyzed. Data from each microarray study were normalized by global normalization.

The predicted target genes and their miRNA binding site seed regions were investigated using TargetScan (release 5.1, http://www.targetscan.org/). The sequences of the predicted mature miRNAs were confirmed using miRBase (release 18.0, November 2011; http://microrna. sanger.ac.uk/).

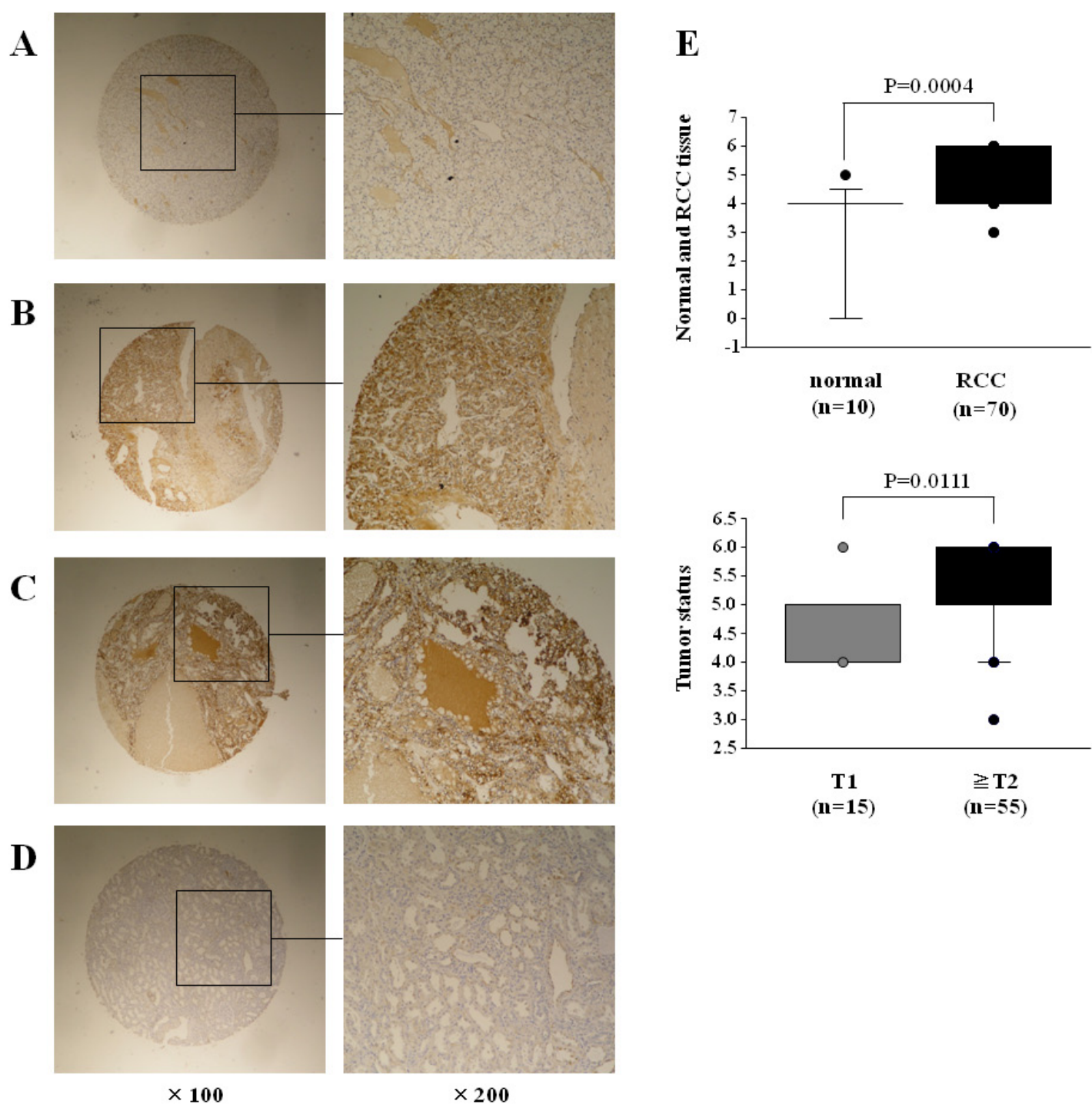

Figure 6: Immunohistochemical staining of $\boldsymbol{T G M}$ in tissue specimens.(A) Positively stained tumor lesion (Grade 1, T1N0M0); (B) positively stained tumor lesion (Grade 1, T2N0M0); (C) positively stained tumor lesion (Grade 1, T3N0M0); (D) Negative staining in normal urocustis tissue. (A, B, C) positive staining in tumor cells: weak (A), strong (B, C). (E) TGM2 expression levels in immunohistochemical staining; upper, TGM2 expression in normal kidney and RCC; lower, correlation between TGM2 expression and clinicopathological parameters in RCC. 


\section{Western blots}

After three days of transfection, protein lysates (20 $\mu \mathrm{g}$ ) were separated by NuPAGE on $4-12 \%$ bis-tris gels (Invitrogen) and transferred to polyvinylidene fluoride membranes. Immunoblotting was done with diluted (1:200) polyclonal TGM2 antibody (HPA029518; SigmaAldrich, St. Louis, MO, USA) and GAPDH antibody (MAB374; Chemicon, Temecula, CA, USA). The membrane was washed and then incubated with goat antirabbit $\mathrm{IgG}(\mathrm{H}+\mathrm{L})-\mathrm{HRP}$ conjugate (BIO-RAD, Hercules, CA, USA). Specific complexes were visualized with an echochemiluminescence (ECL) detection system (GE Healthcare, Little Chalfont, UK), and the expression levels of these genes were evaluated using ImageJ software (ver. 1.43; http://rsbweb.nih.gov/ij/index.html).

\section{Plasmid construction and dual-luciferase reporter assay}

The miRNA target sequences were inserted between the XhoI-PmeI restriction sites in the 3'UTR of the hRluc gene in the psiCHECK-2 vector (C8021; Promega, Madison, WI, USA). Primer sequences for the full-length 3'UTR of TGM2 mRNA (5'-GATCGCTCGAGCCACCTTGATTCCCAATCC-3' and5'-CTTAAACTGTGACTCTTTCCTGTGCAA-3') were designed. 786-O cells were transfected with $15 \mathrm{ng}$ vector, $10 \mathrm{nM}$ microRNAs, and one $\mu \mathrm{L}$ Lipofectamine 2000 (Invitrogen) in $100 \mu \mathrm{L}$ Opti-MEM(Invitrogen). The activities of firefly and Renilla luciferases in cell lysates were determined with a dual-luciferase assay system (E1910; Promega). Normalized data were calculated as the quotient of Renilla/firefly luciferase activities.

\section{Immunohistochemistry}

A tissue microarray of 70 renal cell carcinomas and ten normal kidneys was obtained from US Biomax, Inc. (KD806; Rockville, MD, USA). Detailed information on all tumor specimens can be found at http://www. biomax.us/index.php. The patients' backgrounds and clinicopathological characteristics are summarized in supplementary Table 4 . The tissue microarray was immunostained following the manufacturer's protocol with an UltraVision Detection System (Thermo Scientific). The primary rabbit polyclonal antibodies against TGM2 (Sigma-Aldrich) were diluted 1:400. The slides were treated with biotinylated goat anti-rabbit antibodies. Diaminobenzidine hydrogen peroxidase was the chromogen, and counterstaining was done with $0.5 \%$ hematoxylin. Immunostaining was evaluated according to a scoring method described previously [13]. Each case was scored on the basis of the intensity and area of staining. The intensity of staining was graded on the following scale: 0 , no staining; $1+$, mild staining; $2+$, moderate staining; and $3+$, intense staining. The area of staining was evaluated as follows: 0 , no staining of cells in any microscopic fields; $1+,<30 \%$ of cells stained positive; $2+, 30-60 \%$ stained positive; $3+,>60 \%$ stained positive. A combined staining score (intensity + extension) of $<2$ was low expression, a score between 3 and 4 was moderate expression, and a score between 5 and 6 was high expression.

\section{Statistical analysis}

The relationships between two variables and the numerical values obtained by real-time RT-PCR were analyzed using the Mann-Whitney $U$ test. The relationships among three variables and the numerical values were analyzed using the Bonferroni-adjusted Mann-Whitney $U$ test. The $\chi^{2}$-test was used to evaluate the relationships between immunohistochemical scores of TGM2 expression and clinicopathological factors. Expert StatView analysis software (version 4; SAS Institute Inc., Cary, NC, USA) was used in both cases. In the comparison among three variables, a nonadjusted statistical level of significance of $\mathrm{P}<0.05$ corresponds to a Bonferroniadjusted level of $\mathrm{P}<0.0167$.

\section{ACKNOWLEDGEMENTS}

This study was supported by the Ministry of Education, Sciences, Sports and Culture, Grant-in-Aid for Scientific Research (B and C), 23501298 and 23592340. We thank Ms. Mutsumi Miyazaki for her excellent laboratory assistance.

\section{REFERRENCES}

1. Weng L, Wu X, Gao H, Bing Mu, Xuejun Li, Jin-Hui Wang, Chao Guo, Jennifer M Jin, Zhuo Chen, Covrrubias M, Yuan YC, Weiss LM and Huiquing Wu . MicorRNA profiling of clear cell renal carcinoma by whole-genome small RNA deep sequencing of paired frozen and formalinfixed, paraffin embedded tissue specimens. J Pathol 2010;222:41-51.

2. Fridman E, Dotan Z, Barshack I, Barshak I, David MB, Dov A, Tbak S, Zion O, Benjamin S, Benjamin H, Kuker H, Camila Avivi, Rosenblatt K, Sylvie PC, Ramon J. Accurate molecular classification of renal tumors using microRNA expression. J Mol Diagn 2010;12:687-696.

3. Aben KK, Luth TK, Jassen-Heijinen ML, Mulders PF, Kiemeney DJ, Spronsen DJ. No improvement in renal cell carcinoma survival: a population-based study in The Netherlands. Eur J Cancer 2008;44:1701-1709.

4. Bartel DP. MicroRNAs: genomics, biogenesis, mechanism, and function. Cell 2004;116:281-297. 
5. Calin GA, Croce CM. MicroRNA signature in human cancers. Nat Rev Cancer 2006;6:857-866

6. Esquela-Kerscher A, Slack FJ. Oncomirs-microRNAs with a role in cancer. Nat Rev Cancer 2006;9:102-114.

7. Ichimi T, Enokida H, Okuno Y, Kunimoto R, Chiyomaru T, Kawamoto K, Kawahara K, Toki K, Kawakami K, Nishiyama K, Taujimoto G, Nakagawa M, Seki N. Identification of novel microRNA targets based on microRNA signature in bladder cancer. Int $\mathrm{J}$ cancer 2009; 125:345-352.

8. Kano M, Seki N, Kikkawa N, Fujimura L, Hoshino I, Akutsu Y, Chiyomaru T, Enokida H, Nakagawa M, Matsuda H. miR-145, miR-133a and miR-133b: tumor suppressive miRNAs target FSCN1 in esophageal squamous cell carcinoma. Int J cancer 2010;103:877-884.

9. Kikkawa N, Hanazawa T, Fujimaru L, Nohata N, Suzuki H, Chazono H, Sakurai D, Horiguchi S, Okamoto Y, Seki N. miR-489 is a tumour suppressive miRNA target PTPN11 in hpopharyngeal squamous cell carcinoma. $\mathrm{Br} \mathrm{J}$ cancer 2010;103:877-884.

10. Yoshino H, Chiyomaru T, Enokida H, Kawakami K, Tatarano S, Nishiyama K, Nohata N, Seki N, Nakagawa $\mathrm{M}$. The tumor suppressive function of miR-1 and miR133a targeting TAGLN2 in bladder cancer. Br J cancer 2010;104:808-818.

11. Nohata N, Hanazawa T, Kikkawa N, Mutallip M, Fujimaru L, Yoshino H, Kawakami K, Chiyomaru T, Enokida H, Nakagawa M, Shozu M, Okamoto T, Seki N. Caveolin-1 mediates tumor cell migration and invasion and its regulation by miR-133a in head and neck squamous cell carcinoma. Int J Oncol 2011;38:209-217.

12. Nohata N, Sone Y, Hanazawa T, Fuse M, Kikkawa N, Yoshino H, Chiyomaru T, Kawakami K, Enokida H, Nakagawa M, Shozu M, Okamoto T, Seki N. miR-1 as a tumor suppressive microRNA targeting TAGLN2 in head and neck squamous cell carcinoma. Oncotarget 2011;2:29 44.

13. Nohata N, Hanazawa Y, Kikkawa N, Sakurai D, Fujimura L, Chiyomaru T, Kawakami K, Yoshino H, Enokida H, Nakagawa M, Katayama A, Harabuchi Y, Okamoto T, Seki N. Tumor suppressive microRNA-874 regulates novel cancer networks in maxillary sinus squamous cell carcinoma. Br J cancer 2011;105:833-841.

14. Chiyomaru T, Enokida H, Kawakami K, Tatarano S, Uchida Y, Kawahara K, Nishiyama K, Seki N, Nakagawa M. Functional role of LASP1 in cell viability and its regulation by microRNAs in bladder cancer. urologic oncology 2010 [in press].

15. Tatarano S, Chiyomaru T, Kawakami K, Enokida H, Yoshino H, Hidaka H, Yamasaki T, Kawahara K, Nishiyama K, Seki N, Nakagawa M. miR-218 on the genomic loss region of chromosome $4 \mathrm{p} 15.31$ function as a tumor suppressor in bladder cancer. Int $\mathrm{J}$ Oncol 2011;39:13-21.
16. Kwakami K, Enokida H, Chiyomaru T, Tatarano S, Yoshino H, Ichiro Kagara, Gotanda $\mathrm{T}$, Tachiwada $\mathrm{T}$, Nishiyama K, Nohata N, Seki N, Nakagawa M. The functional significance of MiR-1 and miR-133a in renal cell carcinoma. Eur J Cancer 2011 [in press].

17. Chiyomaru T, Enokida H, Tatarano S, Kawahara K, Uchida Y, Nishiyama K, Fujimaru L, Kikkawa N, Seki N, Nakagawa M. miR-145 and miR-133a function as tumour suppressors and directly regulated FSCN1 expression in bladder cancer. Br J Cancer 2010;102:883-891

18. Nohata N, Hanazawa T, Kikkawa N, Sakurai D, Sasaki K, Chiyomaru T, Kawakami K, Yoshino H, Enokida H, Nakagawa M, Okamoto Y, Seki N. Identification of novel molecular targets regulated by tumor suppressive miR-1/ miR-133a in maxillary sinus squamous cell carcinoma. Int J Oncl 2011;39:1099-1107.

19. Datta J, Kutay H, Nasser MW, Nuovo GJ, Wang B, Majumder S, Liu CG, Volinia S, Croce CM, Schmittgen TD, Ghoshal K, Jacob ST. Methylation mediated silencing of microRNA-1 gene and its role in hepatocellular carcinogenesis. Cancer Res 2008;68:5049-5058.

20. Nasser MW, Datta J, Nuovo G, Kutay H, Motiwala T, Wang B, Suster S, Jacob ST, Ghoshal K. Down-regulation of miro-RNA-1(miR-1) in lung cancer. Suppression of tumorigenic property of lung cancer cells and their sensitization to doxorubicin-induced apoptosis by miR-1. J Biol Chem 2008;283:33394-333405.

21. Yan D, Dong Xda E, Chen X, Wang L, Lu C, Wang J, Qu J, Tu L. MicroRNA-1/206 targets c-Met and inhibits rhabdomyosarcoma development. J Bio Chem 2009;284:29596-29604

22. Uchida Y, Chiyomaru T, Enokida H, Kawakami K, Tatarano S, Kawahara K, Nishiyama K, Seki N, Nakagawa M. MiR-133s induced apoptosis through direct regulation of GSTP1 in bladder cancer cell lines. Urol Oncol 2010 [in press].

23. Ohashi S, Natsuizaka M, Naganuma S, Kagawa S, Kimura S, Itoh H, Kalman RA, Nakagawa M, Darling DS, Basu D, Gimotty PA, Klein-Szanto AJ, Diehl JA, Herlyn M, Nakagawa H. A NOTCH3-mediated squamous cell differentiation program limits expansion of EMT-competent cells that express the ZEB transcription factors. Cancer Res 2011;71:6836-6847.

24. Inge de Kinger, Leonie JM Mekenkamp, Comelis JA Punt, Iris D Nagtegaal. MicroRNAs in colorectal cancer metastasis. J Pathol 2011;224:438-447.

25. White NM, Bao TT, Grigull J, Youssef YM, Girgis A, Diamandis M, Fatoohi E, Metias M, Honey RJ, Stewart R, Pace KT, Bjarnason GA, Yousef GM. miRNA profiling for clear cell renal cell carcinoma: biomarker discovery and identification of potential controls and consequences of miRNA dysregulation. J Urol 2011;186:1077-1083.

26. R.D. Morin, Michael D, Griffith M, Kuchenbauer F, Delaney A, Prabhu AL, Zhao Y, McDonald H, Zeng T, Hirst M, Eaves C, Marra M. Application of massively 
parallel sequencing to microRNA profiling and discovery in human embryonic stem cells. Genome Res 2008;18:610 621.

27. Filipowicz W, Bhattacharyya SN, Sonenberg $N$. Mechanisms of post-transcriptional regulation by microRNAs: are answers in sight? Nat Rev Genet 2008;9:102-114.

28. Folk JE. Transglutaminase. Annu Rev Biochem 1980;49:517-531.

29. Lorand L, Graham RM. Transglutaminase crossing enzyme with pleiotropic functions. Nat Rev Mol Cell Biol 2003;4:140-156.

30. Verma A, Wang H, Manavathi B, Fok JY, Mann AP, Kumar $\mathrm{R}$, Mehta K. Increased expression of tissue transglutaminase in pancreatic ductal adenocarcinoma and its implications in drug resistance and metastasis. Cancer Res 2006;66:1052510533.

31. Mehta K, Fok J, Miller FR, Koul D, Sahin AA. Prognostic significance of tissue transglutaminase in drug resistant and metastatic breast cancer. Clin Cancer Res 2004;10:80688076.

32. Fok JY, Ekmekcoglu S, Mehta K. Implications of tissue transglutaminase expression in malignant melanoma. Mol Cancer Ther 2006;5:1493-1503

33. Hwang JY, Mangala LS, Fok JY, Lin YG, Merrit WM, Spannuth WA, Nick AM, Fiterman DJ, Vivas-Mejia PE, Deavers MT, Coleman BL, Lopez-Berestein G, Mehta K, Sood Ak. Clinical and biological significance of tissue transglutaminase in ovarian carcinoma. Cancer Res 2008;68:5849-5858.

34. Park KS, Kim HK, Lee JH, Choi YB, Park SY, Yang SH, Kim SY, Hong KM. Transglutaminase 2 as a cisplatin resistance marker in non-small cell lung cancer. J Cancer Res Clin Oncol 2010;136:493-502.

35. Yuan L, Siegel M, Choi K, Khosla V, Miller CR, Jacson EN, Piwnica-Worms D, Rich KM. Transglutaminase 2 inhibitor, KCC009,disrupts fibronectin assembly in the extracellular matrix and sensitizes orthotopic glioblastomas to chemotherapy. Oncogene 2007;26:2563-2573

36. Verma A, Mehta K. Tissue tansglutaminase-mediated chemoresistance in cancer cells. Drug Resist Updat 2007;10:144-151.

37. Mangala LS, Fok JY, Zorrilla-Calancha IR, Verma A, Metha K. Tissue transglutaminase expression promotes cell attachment, invasion and survival in breast cancer cells. Oncogene 2007;26:2459-2470.

38. Ai L, Kim WJ, Demircan B, Dyer LD, Bray KJ, Skehan RR, Massoll A,Brown KD. The transglutaminase 2 gene, a potential molecular marker for chemotherapeutic drug sensitivity, is eigenetically silenced in breast cancer. Carcinogenesis 2008;29:510-518.

39. Shao M, Cao L, Shen C, Satpathy M, Chelladurai B, Bigsby RM, Nakshatri H, Matei D. Epithelial-to-mesenchymal transition and ovarian tumor progression induced by tissue transglutaminase. Cancer Res 2009;69:9192-9201.

40. Sobin LH, Wittekind C. TNM Classification of Malignant Tumours. 6th edn. International Union Against Cancer (UICC). Wiley-Liss;2009.p.255-257. 